によるものであった，電子線による全身照射法は症例が 少いこともあり数年に 1 回程度報告され症例報告の感が ある. 演題265は $\gamma$ 線による全身照射法であるが, コバル 卜を用いた報告は国内では少なく貴重である．コバルト は安定した出力が得られる反面エネルギーが低いことか ら成人に対する照射は空間線量分布の均等性に留意する 必要があり，特に肺線量は注意する必要がある，演者ら は，全身照射用 TAR 表を作成し測定の合理化を図った ものであるが, TAR は体積変化とともに変化するとも 述べている，全身照射におけるドジメトリーの問題点は この点にあると思われる. 昨年の総会でも日大板橋病院 山田氏が発表されたTPR と体積の関係もこのテーマに 沿ったものであった。 モデル的な正方形のファントムで はあまり差がでないが，骨盤部の様な直方体では，前後 方向と左右方向で差がでることを経験している．演者が 指摘したように，腔内線量計による実測が予定線量より $4 \sim 10 \%$ 低いのも，フアントムと生体の違いがあるにし ても妥当な数值ではないかと思える．全身照射における ドジメトリーはまだまだ研究対象であろう。

演題266，267は，Mycosis Fungoides の治療を行う際 の技術的検討である. 照射方法は Stanford 大学の方法 に集約できるが，電子線を使用するため装置間，スキャ ッタリングフォイルの材質の異なりにより測定データが 違う所に発表の意義がある，この治療法の問題点は，藤 森（弘前大）の線量率が低いので治療時間が長いこと， 村田 (金沢大) の線量評価点をどの点にするか, 菊地 (東 京女子医大）のX線含有率を少なくすることである．治 療時間が長いことで患者の体位固定等に工夫をする問題 も生じる. 線量評価点の問題は，過去の報告においても 大体腹部の線量に注目しているようで, 照射野の平担度 も照射野中心を基準に測定を行うことから腹部で統一し たらどうか．X線含有率を少なくする必要性は文献（菌 状息肉症に対する電子線全身照射療法：古賀健治他：日 医放会誌：45(2)，364-372，1985）にあるように「4Gy/ 16〜18ケ月前後の X 線量は回復不能な汎血球減少症を引 き起す線量であり，この線量を越える照射は避けるべき である」とあるからである，X線含有率を多くする原因 は，エネルギーを下げるために使用するアクリル板にあ る. X線含有率低減の合理的な対策として, 菊地(前出) の述べた方法の様に, 治療開始時は腫瘍の大きさにより 少しエネルギーの高いもの $(6 \sim 8 \mathrm{MeV})$ で行い腫瘍の縮 少によりアクリル板などでエネルギーを下げて治療する なれば，総合的にX線含有率を少なくすることができる。 臨床に值する方法である，いずれにしてもX線含有率の
問題が課題として残る。

\section{治療-12＼cjkstart温熱療法- 1（演題番号443～445）}

木村千明(愛知県がんセンター病院放射線治療部技術科) 八イパーサーミアは, 体外より種々なエネルギーを投 与して腫瘍領域のみの温度を上昇させ腫瘍細胞を死滅さ せることを目的とした治療法で，この目的を果たすため に現在主に用いられている RF 波，マイクロ波等の電磁 波では，電磁波照射により生体内分子自身の発熱を利用 したもので，生体は，電気的特性が均一でなく不均一な 温度分布になることは, 過去多くの研究者によって報告 されている，また，組織の熱伝導あるいは血流による熱 拡散は，ハイパーサミアで最も問題となる現象である。 しかし血流量やその割合は，腫瘍部位，大きさ，等によ つても異なることも広く知られていることである。した がって，夫々の加温部位に合致したシミュレーションが 行われるべきで, 放射線の場のごとく，均一な水ファン 卜ムで得られた線量分布を種々な不均一な生体に応用す ることは，ハイパーサーミアの場合は，かなりの努力が 必要となる. 生体内温度分布のシミュレーションの一方 法としてファントム実験が行われる。

今回の三題の内, 演題 444,445 は, 第39回総会におい て大阪市大が報告したものと同様な結果となっており， 今回の報告にあるように組織として菜種を用いた理由が 不明であるが，流量測定に RI を検出媒体として利用し たことが興味をそそられた。

演題 443 は, この数年温度分布シミュレーションに努力 され，今回も興味深い報告であるが，種々な腫瘍に対し 今回の血管配置をどのように変化させるか今後の問題は ある。また当実験と計算シミュレーションとの一致性を 含めて近日中に報告されると思う。

\section{治療-13＼cjkstart温熱療法- 2（演題番号446～448）}

津田政行（東海大病院）

温度分布の実際を非侵襲的にマイクロ波 CT で得られ た演題446の報告は,温熱療法でわれわれが最も欲してい る情報の問題解決に一歩踏み込んだものだけに，今後の 展開が期待される．分解能の改善や患者支持の方法等ま だ困難な問題はあるが，加温中に分布測定が可能（愛知 がん木村の質問）ということでもあり，実用化が望ま れる。

演題447は, 銅綿混紡のシールド織布を温熱療法に利用 しようというものである. 所期の治療を完遂するための 一方法として, 臨床的に応用できるであろう。適用周波 
数域に関する質問（神戸大 村上）があったが，シール ド材の一般的な特性として公表されているデータはある ものの，実際には試みていないという答えであった。

演題448は, 異常温度の発生原因を解明した報告であ る. 温度計の経時変化も調べ, 温度変化・直線性ともに 問題がなかったことにも言及された．温熱治療装置の導 入が年々増えているにもかかわらず，その保守管理に関 する報告がない．細かな日常のトラブルの記録集積が, 比較的新しいこの分野の QA-QC に結びつくものと思わ れる。

\section{超音波- 1 臨床評価（演題番号283～288）}

堀 洋児（慈恵医大病院）

本セッションは, 心臓の壁厚の計測に関するのが 3 演 題, 乳腺の集団検診, ゼログラフィとの対比の 3 演題の 発表があり, 今回初めて乳腺の集団検診についての報告 があった。

演題283は超音波伝達媒体（オイルゼリー）を用いて右 室前壁厚について検討し右室前壁厚は，男女とも心室中 隔, 左室後壁厚に比べ加齢による影響が強いことを報告 した.

質問（聖マリ 中川）加齢による何が影響している のか，Fatだとすると男女によるばらつきがあると思う 范.

\section{答 検討しているところである。}

右室前壁は描出しずらいために壁厚の報告は少なく今 回伝達媒体を使用して興味あるデータが報告されたが今 後伝達媒体の厚みや高周波数プローブ等の検討してより 精度の高いデータにまとめられることを期待します。

演題284は心のう液貯留時の右室前壁厚計測は脂肪層 と前壁が分離するように GAIN を調整して計測する必 要があると報告した.

演題285は左室壁厚の計測の問題を精度テストと剖検 心での計測から心エコーで使用されるセクタースキャン の欠点である横方向の計測に注意し，また心室内の肉柱 の影響を考慮すべきだと報告した。

超音波における計測は画像上で行っているためにいる んな因子がからんで客観的でない場合が多く正確な值を 求めるためにも従来の装置に設置してあった Aモードで ピーク〜ピークの值を計ればより正確だと思うが現在の 装置は取去っているが設置すべきだと思っている。

演題286，287は Water Path 法（オクトソン）での乳 腺の集団検診の報告で短時間で多く受診者を検査でき， $T_{1}$ の乳癌も発見され本装置による集団検診の有用性を
報告した。

質問 （聖マリ 中川）検診がゆえ医師の触診をはぶ いているが，それと False Negative 10例の関係は。

答 専門の医師でないと触診の診断率が良くないのと 触診の数も $40 \sim 50$ 人が限度で短時間で多数の人を検査す るために触診ははぶいている，10例の内 3 例は E 領域で 7 例は画像として描出していなかった。 今後 Gain 調整 やスキャン方法に検討をくわえていきたい。

質問 （慈恵 松原）フォーカスポイントからはずれ た場合の画像の影響は。

答 フォーカスポイントで $1.1 \mathrm{~mm}$ でその前後 $2 \mathrm{~cm}$ で1.5 mmであり $4 \mathrm{~cm}$ の間に乳腺をいれている。

質問 （都職青山 永田）乳腺では高周波数のプロ一 ブを使用するのだが本装置では $4.5 \mathrm{MHz}$ を使用してい るが。

答 周波数を上げると減衰が多くなり 1 人 1 人 Gain を調節しなくてはならなくオペレータの操作を少なくす るために $4.5 \mathrm{MHz}$ を使用しているが分解能のこともあ り現在では $5.5 \mathrm{MHz}$ のものを使用している.

集団検診に本装置は成果を上げているが周波数, 走査 間隔，画像の結像等の問題があり，また集団検診のシス テムでも触診は加えるべきであり，今後検討をかさねて 集団検討をかさねて集団検診に寄与することを期待しま す.

演題287は触診困難な乳癌の早期発見に超音波とゼロ グラフィーの併用は有用であると報告した.

\section{超音波- 2 装置他（演題番号289～294）}

大波 忠 (東京都設計事務所健保組合健康管理センター) このセッションは超音波装置等 6 演題であり, ドップ ラー関係が 3 題含まれている.

演題289は,オイルゼリーを加工した試作ファントムを 用い定常流波形が得られる物質としてベビーパウダーを ドップラー源とする流量測定実験である。

演題290は， $7.5 \mathrm{MHz}$ メカニカルセクタの使用報告で あり、リニア装置との比較に打いて特長を報告している。

演題291は, 門脈枝を透明なオイルゼリーに埋め込み, 模型として立体構造が分るだけでなく，超音波画像とし て理解できるファントームを目指した試作である。

演題292は, 超音波ドップラー血流測定の測定精度およ び問題点について，さらに直接血管内の血流速度を計る ドップラーカテーテルによる実験報告である.

演題293は，試作ファントームによる，7.5 MHz と20 $\mathrm{MHz}$ との石灰化に扔ける超音波像の対比である. 